\title{
誘導結合プラズマ発光分析法によるコメ 1 粒中の無機元素 の定量
}

\author{
進藤久美子 ${ }^{\circledR *}$, 安井 明美*
}

\section{Determination of mineral contents in a single grain of rice by ICP-AES}

\author{
Kumiko SHINDOH and Akemi YASUI * \\ * National Food Research Institute, Ministry of Agriculture, Forestry and Fisheries, 2-1-2 Kannondai, \\ Tsukuba-shi, Ibaraki 305
}

(Received 26 May 1997, Accepted 2 July 1997)

Pretreatment methods for the determination of mineral contents in a sample with a small amount of materials, such as a single grain of rice, were investigated. To pretreat a large number of samples with a small amount of materials simultaneously, two kinds of wet-digestion methods, nitric acid- hydrogen peroxide or nitric acid-perchloric acid, using a borosilicate glass test tube and a dry-blockbath, were tested. In digestion with nitric acid-hydrogen peroxide, the temperature of the dry-blockbath was maintained at $150^{\circ} \mathrm{C}$, while in digestion with nitric acid-perchloric acid, the temperature was raised up to $250^{\circ} \mathrm{C}$ in the final step to evaporate perchloric acid. These methods enabled us to digest 32 samples simultaneously in 2 hours. Sample solutions were analyzed by ICP-AES. When nitric acid-hydrogen peroxide was used, the values of $\mathrm{P}, \mathrm{K}, \mathrm{Mg}, \mathrm{Ca}, \mathrm{Zn}, \mathrm{Mn}, \mathrm{Fe}$ and $\mathrm{Cu}$ measured in about $20 \mathrm{mg}$ (corresponding to a single grain of rice) of the certified reference material (NIES No.10 Rice Flour-Unpolished) were in good agreement with the certified values. The RSD of the measured values of $\mathrm{Fe}$ and $\mathrm{Cu}$ were larger than those of other minerals due to the low contents. When nitric acid-perchloric acid was used, the measured value of $\mathrm{Mn}$ was low. A high temperature $\left(250^{\circ} \mathrm{C}\right)$ was considered to lead to a loss of Mn. By using a digestion method with nitric acid-hydrogen peroxide, we investigated the variations in the mineral contents in 100 single grains of unpolished and polished rice, "Nipponbare" (Oryza sativa) japonica cultivar, which grew in the same field. Each $2 \sigma$ value of unpolished rice corresponded to about $15 \%$ of the average concentration values of $\mathrm{P}, \mathrm{K}, \mathrm{Mg}$ and ranged from 20 to $40 \%$ of the average concentration values of $\mathrm{Ca}, \mathrm{Zn}, \mathrm{Mn}, \mathrm{Fe}$ and $\mathrm{Cu}$.

Keywords : determination of mineral contents; wet digestion; ICP-AES; variation in mineral contents in single grains of rice.

$$
1 \text { 緒言 }
$$

官能検査に代わる炊飯米の評価方法として，動的粘弾 性試験 ${ }^{12)}$ や稲津による3)テクスチュロメーター, 岡留ら

*農林水産省食品総合研究所：305 茨城県つくば市観音 台 2-1-2
による改良型テンシプレッサー4)のような, 炊飯米数粒 もしくは 1 粒を用いた機器による物性測定手法が検討 されてきた。これらの手法は迅速な測定法であるが, 1 粒を用いると相対標準偏差が大きいために, 繰り返し測 定が行われている. 変動の原因として, 炊飯米の食味特 性に影響を及ぼすアミロース ${ }^{5)}$, タンパク質6)などの成 
分のほか, 無機元素7)などの微量成分が考えられる.

コメ 1 粒による特性評価においては，1 粒の変動を把 握する必要があり，そのためにはコメ 1 粒の成分含有 量を測定できる少量試料の測定法の開発が必要である. コメのアミロースでは, 玄米半粒 2 粒を用いた測定法 が検討されており ${ }^{8)}$, タンパク質 (窒素) ではインドフ エノール法により玄米 1 粒中の含有量が求められ, 穂 内の着粒位置による含有量の変異も検討されている ${ }^{9)}$.

又, 水分, タンパク質では非破壊的な方法として光ファ イバーを用いた近赤外分光法 ${ }^{10)}$ も検討されている．無 機元素では，玄米 1 粒中の $\mathrm{Mg}, \mathrm{K}$ を測定し， $\mathrm{Mg} / \mathrm{K}$ 比を穂内の着粒位置で示した報告がある ${ }^{11)}$. 非破壊法 あるいははい（胚）を含まない半粒を用いれば，成分を 測定した粒をそのまま育種材料として使うこともでき， こうした意味からも少量試料を用いる分析法確立の必要 性は高い.

本報告では，コメ 1 粒のような少量試料中の無機元 素測定法を検討した. 食品の無機元素測定のための試料 溶液調製には乾式灰化, 湿式分解, 希酸抽出などの前処 理を行うが，乾式灰化の場合には，無機元素の多い玄米 では灰化の途中で表面に塩が凝集して灰化が進まなくな り, 一度可溶性塩を溶出させてから更に灰化する必要が あること, 希酸抽出の場合には, 粒のままの玄米からは 無機成分の抽出が行いにくいことなどから, 湿式分解法 を選択した. Tracy らは, 乾重量 $0.25 \sim 0.50 \mathrm{~g}$ の生体試 料の分解に, 容器として $10 \mathrm{ml}$ の試験管を, 試料分解 装置として試験管を装てんし, 温度と時間のプログラム できるアルミブロックを用いて湿式分解を行ってい る $^{12)}$. 少量の試料の分解には密閉式のテフロン分解容 器が多用されているが, 本報告ではコメ多数点をより迅 速に処理するため, ホウケイ酸ガラス製ねじ付き試験管 を用いて，これを多数装てんできる乾式ブロック浴で加 熱分解した. 分解が迅速に行われるよう, 硝酸に過酸化 水素あるいは過塩素酸を組み合わせた.この方法は 1 粒のような少量のコメ中の, $\mathrm{P}, \mathrm{K}, \mathrm{Mg}, \mathrm{Ca}, \mathrm{Zn}$, $\mathrm{Mn}, \mathrm{Fe}, \mathrm{Cu}$ の測定の前処理法として適用可能であり, 又この測定法を用いて, 同一産地内の “日本晴” 1 粒の 無機元素の変異を明らかにしたので報告する.

\section{2 実験}

\section{$2 \cdot 1$ 試 料}

少量の試料の前処理, 測定法の検討には, 国立環境研 究所の “玄米粉末” 標準試料 NIES No.10, Rice FlourUnpolished, $\mathrm{a} \sim \mathrm{c}$ の 3 種類を用いた. コメ 1 粒の無機 元素の測定には “日本晴” 玄米（1995 年, 農業研究セ
ンタ一産）から未熟粒，被害粒を除いたものを用いた。 又，この玄米をサ夕ケ製のワンパス式精米機で歩留まり 90.6\% にとうせい（搗精）し，砕粒等を除いた整粒で， 胚がきれいに取り除かれている精白米も用いた。

玄米標準試料の乾重量は標準試料説明書に記載の常圧 $85^{\circ} \mathrm{C}, 4$ 時間の乾燥方法により求めた. コメ 1 粒の乾 重量は, 常圧 $135^{\circ} \mathrm{C}, 20$ 時間の通風加熱乾燥法 ${ }^{13)}$ で測 定した。

\section{$2 \cdot 2$ 試薬及び標準溶液}

試料の分解に用いた硝酸, 過酸化水素, 過塩素酸はい ずれも原子吸光分析用 (和光純薬製) を, その後の試料 溶液調製には，精密分析用 $20 \%$ 塩酸（和光純薬製）を 20 倍に希釈して用いた。希釈には，イオン交換した水 を逆浸透膜（ミリポア製，Milli-RO）を通し，更に活性 炭一イオン交換樹脂-ミクロフィルター $(0.22 \mu \mathrm{m})$ (ミリ ポア製，Super-Q システム）を順次通過させたものを用 いた．誘導結合プラズマ発光分析装置（ICP-AES）に よる測定では，検量線の作成には関東化学製の原子吸光 測定用標準液を用いて, 8 元素の混合標準液を調製し た。

\section{$2 \cdot 3$ 装置及び測定条件}

加熱に用いた乾式ブロック浴はサイニクス製 $\mathrm{AL}-$ 1000 を，ホウケイ酸ガラス製ねじ付き試験管はパイレ ックス製で, キャップはテフロンライナー付きの容量 $11 \mathrm{ml}$ （直径 $16 \mathrm{~mm} \times$ 長さ $100 \mathrm{~mm} \times$ 口内径 $9 \mathrm{~mm}$ ）の ものを用いた．無機元素の測定には ICP-AES，Leeman Lab 製 JICP-PS3000 UV を用いた．測定した元素と用 いた波長は $\mathrm{P}$ (214.910)，K (766.490)， Mg (279.553)， Ca (393.366), Mn (257.610), Zn (213.856), Fe (238.204), $\mathrm{Cu}(24.754 \mathrm{~nm})$ である. プラズマガスは $13 \mathrm{l} / \mathrm{min}$, 補助 ガスなし，ネブライザーガス圧 $40 \mathrm{psi}$ ，観測位置は $\mathrm{Mn}$ で調整した。

\section{$2 \cdot 4$ 無機元素含有量の測定}

標準試料は約 $20 \mathrm{mg}$, コメでは 1 粒を, 微量てんび んで $0.1 \mu \mathrm{g}$ まで重量を測定した後，ホウケイ酸ガラス製 ねじ付き試験管に移し, 硝酸一過酸化水素又は硝酸一過塩 素酸による湿式分解を乾式ブロック浴で加熱することに より行った.

すなわち, 硝酸-過酸化水素による分解は, 硝酸 $1 \mathrm{ml}$ を加え, $150^{\circ} \mathrm{G}$ で 1 時間分解した後, 過酸化水素を 0.02 0.03 ml ずつ計 $1 \mathrm{ml}$ 滴下して更に分解し，そのま ま $150^{\circ} \mathrm{C}$ で残った硝酸を蒸発させた. 過酸化水素滴下 
の時点で硝酸がかなり少量，あるいはなくなった場合に は，硝酸を $0.3 \mathrm{ml}$ 加えてから過酸化水素を滴下した。

硝酸-過塩素酸による分解は, 硝酸 $1 \mathrm{ml}$ を加えて $150^{\circ} \mathrm{C}$ で分解し, 泡立ちや激しい褐色煙の発生が収まっ たところで，試験管を乾式ブロック浴から下ろし，過塩 素酸 $0.1 \mathrm{ml}$ を加えて $210^{\circ} \mathrm{C}$ で更に分解した．液が黒褐 色に変化したときには硝酸を加えて更に分解し, 分解液 が透明あるいは淡黄色であることを確認してから $250^{\circ} \mathrm{G}$ で過塩素酸を蒸発させ，できるだけ乾固寸前に乾式ブロ ック浴から取り出して加熱を終了させた。

試験管内の分解物には $1 \%$ 塩酸 $2 \mathrm{ml}$ を加え, キャッ プを締めて振り混ぜ, 溶解させた後, IGP-AES で多元 素同時定量し, 無機元素含有量を, 乾重量当たりもしく は 1 粒に含まれる全量で求めた.

\section{3 結果及び考察}

\section{3 ・1 ホウケイ酸ガラス製ねじ付き試験管を用いた少 量試料の分解}

試験管は分解容器として細長いため, 硝酸での分解の 初期や過酸化水素の滴下時にふきあがってこないように 注意する必要があるが，問題なく分解を行うことができ た。

硝酸-過塩素酸分解は, 有機物の残った状態で過塩素 酸を乾固させると爆発の危険があるので, 黒褐色への変 色に注意を払う必要があるが，今回は約 $20 \mathrm{mg}$ の玄米 粉末標準試料, 玄米 1 , 粒とも, 残った過塩素酸がすべ て無色あるいは淡黄色となり，更に硝酸を加えて分解を 要するものは出なかった. 又, 加熱を過塩素酸の乾固寸 前で終了させるため, 過塩素酸が残るが，ねじ付き試験 管は, 分解容器として口が狭く, 細長いため, 乾式ブロ ック浴のアルミブロックの高さを試験管の長さに合わせ ても, 試験管内に充満している過塩素酸蒸気が, 試験管 を乾式ブロック浴から取り出して冷却したときに凝結 し, 更に過塩素酸量が増えることが認められた。一般に 試料溶液の酸濃度が高くなると ICP-AES の発光強度に 影響を与えるため ${ }^{14)}, 1 \%$ 塩酸で調製した玄米の測定モ デル溶液へ過塩素酸の添加実験を行い, 分解終了時に残 る過塩素酸の影響を検討した. その結果を Table 1 に 示す. 分解終了.時に実際に残った過塩素酸量は $10 \mu \mathrm{l}$ 程 度と Table 1 で添加した量より少量であり, 測定值に 与える影響は, ICP-AES の発光強度の点からも, 試料 溶液の希釈の点からも，ほとんど無視できると考えられ る. 分解後残った酸を蒸発させる操作も含めて, 硝酸過酸化水素, 硝酸-過塩素酸の分解とも, 本実験ではね じ付き試験管 32 本分の分解を約 2 時間で行うことがで
Table 1 Effect of amount of perchloric acid added on the measurement of mineral contents of a single grain of rice by ICP-AES

\begin{tabular}{lccc}
\hline & \multicolumn{3}{c}{$\mathrm{HClO}_{4}$ addition/ $\left.\mu \mathrm{l}\right)$} \\
\cline { 2 - 4 } & 0 & $25^{\dagger}$ & $50^{\dagger}$ \\
\hline $\mathrm{P}$ & 100 & 98 & 98 \\
$\mathrm{~K}$ & 100 & 98 & 94 \\
$\mathrm{Mg}$ & 100 & 99 & 99 \\
$\mathrm{Ca}$ & 100 & 99 & 98 \\
$\mathrm{Zn}$ & 100 & 99 & 99 \\
$\mathrm{Mn}$ & 100 & 100 & 98 \\
$\mathrm{Fe}$ & 100 & 99 & 98 \\
$\mathrm{Cu}$ & 100 & 100 & 100 \\
\hline
\end{tabular}

Model solution for unpolished rice grain : $2 \mathrm{ml}$ of $1 \%$ hydrochloric acid solution containing $\mathrm{P} 30, \mathrm{~K} 30$, $\mathrm{Mg}$ 15, Ca 1, Zn 0.3, Mn 0.3, Fe 0.1 and $\mathrm{Cu}$ $0.1 \mathrm{ppm} .{ }^{\dagger}$ Calculated values except for the volume of $\mathrm{HClO}_{4}$

きた。

\section{$3 \cdot 2$ 玄米粉末標準試料の測定}

粉末の均質化された玄米標準試料を用いて，玄米 1 粒分の約 $20 \mathrm{mg}$ の試料の溶液化を行い, 測定值の正確 さと精度を検討した.この結果を Table 2 に示す.

硝酸一過酸化水素分解では $\mathrm{P}, \mathrm{K}, \mathrm{Mg}, \mathrm{Ca}, \mathrm{Zn}, \mathrm{Mn}$ とも保証值とよく一致しており，測定值のばらつきも相 対標準偏差で $5 \%$ 内に収まっていた．含有量の少ない $\mathrm{Fe}, \mathrm{Cu}$ では，採取試料が少量であることが強く影響し てばらつきが若干大きくなっているが, 測定值は保証值 と一致あるいは極めて近似していた。

硝酸一過塩素酸分解では，P，K， Mg， $\mathrm{Ca} ， \mathrm{Zn}$ の測 定值は保証值と一致した.これらの元素では測定のばら つきも相対標準偏差でほぼ $3 \%$ 以内に収まっており, 良好な結果であった。 Fe と $\mathrm{Gu}$ はばらつきが大きくな っているが，保証値と一致あるいは極めて近似してい た. Mn の測定値は明らかに低値を示した。これを改善 するため, 一連の分解をすべて $150^{\circ} \mathrm{C}$ で行い, 残った 過塩素酸を $150^{\circ} \mathrm{C}$ で加温しながら窒素を吹き込んで蒸 発させることにより, 6 点並行分析の結果, NIES No.10-a で保証值 $34.7 \pm 1.8$ に対し $34.7 \pm 1.3$, b が $31.5 \pm 1.6$ に対し $30.1 \pm 1.7$, c が $40.1 \pm 2.0$ に対し $38.5 \pm 1.4$ となり，Mnの損失を防ぐことができた．過 塩素酸を蒸発させるために $250^{\circ} \mathrm{C}$ と高温にしたことが 主な原因と考えられる．但しその操作は完了まで長時間 を要した. 過塩素酸の蒸発まで 2 時間で行うことが可 能な今回の方法は，Mnを定量するための前処理法とし 
Table 2 Measured values of sample of NIES No. 10 a c Rice Flour-Unpolished (20 mg) digested with acid using a borosilicate glass test tube as a vessel

\begin{tabular}{|c|c|c|c|c|}
\hline & & Certified value & $\mathrm{HNO}_{3}-\mathrm{H}_{2} \mathrm{O}_{2}$ digestion ${ }^{\dagger}$ & $\mathrm{HNO}_{3}-\mathrm{HClO}_{4}$ digestion ${ }^{\dagger}$ \\
\hline \multirow{4}{*}{$\mathrm{P}$} & & wt $\%$ (d.w.) & & \\
\hline & $\mathrm{a}$ & $0.340 \pm 0.007$ & $0.336 \pm 0.013(4.0 \%)$ & $0.339 \pm 0.007(2.1 \%)$ \\
\hline & $\mathrm{b}$ & $0.315 \pm 0.006$ & $0.312 \pm 0.013(4.3 \%)$ & $0.319 \pm 0.010(3.2 \%)$ \\
\hline & $\mathrm{c}$ & $0.335 \pm 0.008$ & $0.327 \pm 0.007(2.2 \%)$ & $0.333 \pm 0.007(2.2 \%)$ \\
\hline \multirow[t]{3}{*}{$\mathrm{K}$} & $\mathrm{a}$ & $0.280 \pm 0.008$ & $0.279 \pm 0.012(4.3 \%)$ & $0.280 \pm 0.004(1.5 \%)$ \\
\hline & $\mathrm{b}$ & $0.245 \pm 0.010$ & $0.250 \pm 0.012(4.9 \%)$ & $0.256 \pm 0.004(1.7 \%)$ \\
\hline & $\mathrm{c}$ & $0.275 \pm 0.010$ & $0.281 \pm 0.010(3.5 \%)$ & $0.283 \pm 0.006(2.2 \%)$ \\
\hline \multirow[t]{3}{*}{$\mathrm{Mg}$} & a & $0.134 \pm 0.008$ & $0.134 \pm 0.005(3.9 \%)$ & $0.135 \pm 0.003(2.5 \%)$ \\
\hline & $\mathrm{b}$ & $0.131 \pm 0.006$ & $0.132 \pm 0.006(4.8 \%)$ & $0.135 \pm 0.003(2.3 \%)$ \\
\hline & $\mathrm{c}$ & $\begin{array}{c}0.125 \pm 0.008 \\
\mu \mathrm{g} / \mathrm{g} \text { (d.w.) }\end{array}$ & $0.126 \pm 0.003(2.6 \%)$ & $0.129 \pm 0.002(1.8 \%)$ \\
\hline \multirow[t]{3}{*}{$\mathrm{Ca}$} & $\mathrm{a}$ & $93 \pm 3$ & $89.8 \pm 3.1(3.4 \%)$ & $89.9 \pm 2.5(2.7 \%)$ \\
\hline & $\mathrm{b}$ & $78 \pm 3$ & $76.4 \pm 2.4(3.2 \%)$ & $78.1 \pm 2.4(3.1 \%)$ \\
\hline & $\mathrm{c}$ & $95 \pm 2$ & $93.7 \pm 2.4(2.5 \%)$ & $93.7 \pm 0.7(0.8 \%)$ \\
\hline \multirow[t]{3}{*}{$\mathrm{Zn}$} & a & $25.2 \pm 0.8$ & $24.0 \pm 0.8(3.2 \%)$ & $24.8 \pm 0.6(2.5 \%)$ \\
\hline & $\mathrm{b}$ & $22.3 \pm 0.9$ & $21.4 \pm 0.6(2.8 \%)$ & $22.5 \pm 0.4(1.9 \%)$ \\
\hline & $\mathrm{c}$ & $23.1 \pm 0.8$ & $22.8 \pm 0.7(3.0 \%)$ & $23.0 \pm 0.4(1.9 \%)$ \\
\hline \multirow[t]{3}{*}{$\mathrm{Mn}$} & $\mathrm{a}$ & $34.7 \pm 1.8$ & $33.3 \pm 1.5(4.4 \%)$ & $26.7 \pm 1.4(5.1 \%)$ \\
\hline & $\mathrm{b}$ & $31.5 \pm 1.6$ & $30.0 \pm 1.5(4.9 \%)$ & $24.5 \pm 1.8(7.4 \%)$ \\
\hline & $\mathrm{c}$ & $40.1 \pm 2.0$ & $38.1 \pm 1.2(3.0 \%)$ & $29.8 \pm 1.3(4.3 \%)$ \\
\hline \multirow[t]{3}{*}{$\mathrm{Fe}$} & $\mathrm{a}$ & $12.7 \pm 0.7$ & $11.5 \pm 0.8(6.7 \%)$ & $12.1 \pm 0.9(7.5 \%)$ \\
\hline & $\mathrm{b}$ & $13.4 \pm 0.9$ & $13.4 \pm 1.9(14.3 \%)$ & $13.0 \pm 1.5(11.4 \%)$ \\
\hline & c & $11.4 \pm 0.8$ & $9.9 \pm 1.0(10.4 \%)$ & $10.7 \pm 1.1(10.1 \%)$ \\
\hline \multirow[t]{3}{*}{$\mathrm{Gu}$} & $\mathrm{a}$ & $3.5 \pm 0.3$ & $3.3 \pm 0.3(10.1 \%)$ & $3.8 \pm 0.4(9.7 \%)$ \\
\hline & $\mathrm{b}$ & $3.3 \pm 0.2$ & $3.2 \pm 0.1(3.8 \%)$ & $4.0 \pm 0.4(9.5 \%)$ \\
\hline & c & $4.1 \pm 0.3$ & $4.4 \pm 0.2(3.5 \%)$ & $4.3 \pm 0.4(9.3 \%)$ \\
\hline
\end{tabular}

${ }^{\dagger} \mathrm{Av} \pm \mathrm{SD}(\mathrm{RSD}), n=6$

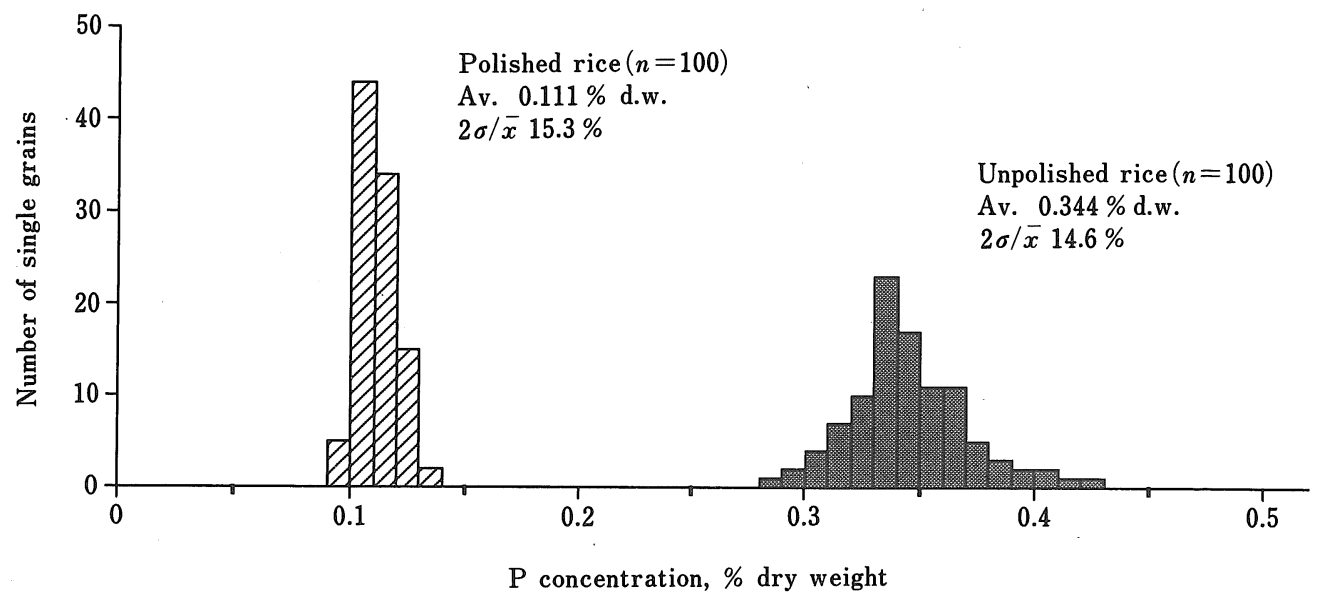

Fig. 1 Variation of P concentration in single grains of "Nipponbare" 
Table 3 Variation of mineral contents in single grains of unpolished rice "Nipponbare" $(n=100)^{\dagger}$

\begin{tabular}{|c|c|c|c|c|c|c|c|c|}
\hline & $\mathrm{P}$ & $\mathrm{K}$ & $\mathrm{Mg}$ & $\mathrm{Ca}$ & $\mathrm{Zn}$ & $\mathrm{Mn}$ & $\mathrm{Fe}$ & $\mathrm{Cu}$ \\
\hline \multicolumn{9}{|c|}{ Concentration } \\
\hline & \multicolumn{2}{|c|}{ wt $\%$ (d.w.) } & & \multicolumn{2}{|c|}{$\mu g / g(d . w)}$. & & & \\
\hline Av. & 0.344 & 0.276 & 0.138 & 90.3 & 23.4 & 35.7 & 10.4 & 3.3 \\
\hline Max. & 0.420 & 0.342 & 0.165 & 125 & 48.2 & 52.0 & 15.3 & 4.4 \\
\hline Min. & 0.287 & 0.237 & 0.118 & 68.3 & 17.2 & 23.8 & 7.1 & 2.3 \\
\hline $2 \sigma / \bar{X}, \%$ & 14.6 & 14.7 & 13.6 & 26.4 & 35.3 & 39.7 & 30.6 & 26.7 \\
\hline \multicolumn{9}{|c|}{ Content in single grains } \\
\hline \multicolumn{3}{|c|}{$\mu g$} & & & & & & \\
\hline Av. & 66.7 & 53.5 & 26.7 & 1.75 & 0.45 & 0.69 & 0.20 & 0.06 \\
\hline Max. & 80.1 & 62.0 & 31.9 & 2.33 & 0.78 & 1.06 & 0.30 & 0.09 \\
\hline Min. & 55.1 & 43.1 & 21.8 & 1.11 & 0.30 & 0.42 & 0.12 & 0.04 \\
\hline $2 \sigma / \bar{X}, \%$ & 16.4 & 15.3 & 16.5 & 24.6 & 32.9 & 39.9 & 35.9 & 29.8 \\
\hline
\end{tabular}

${ }^{\dagger}$ Wet digestion with $\mathrm{HNO}_{3}-\mathrm{H}_{2} \mathrm{O}_{2}$. Dry weight of single grains: Av. 19.4mg, Max. 22.6mg, Min. 15.1mg, 2б/X $16.4 \%$

Table 4 Variation of mineral contents in single grains of polished rice "Nipponbare" $(n=100)^{\dagger}$

\begin{tabular}{|c|c|c|c|c|c|c|c|}
\hline & $\mathrm{P}$ & $\mathrm{K}$ & $\mathrm{Mg}$ & $\mathrm{Ca}$ & $\mathrm{Zn}$ & $\mathrm{Mn}$ & $\mathrm{Cu}$ \\
\hline \multicolumn{8}{|c|}{ Concentration } \\
\hline & \multicolumn{2}{|c|}{ wt $\%$ (d.w.) } & \multicolumn{4}{|c|}{$\mu \mathrm{g} / \mathrm{g}$ (d.w.) } & \\
\hline Av. & 0.111 & 0.076 & 0.030 & 51.8 & 17.1 & 10.5 & 3.0 \\
\hline Max. & 0.135 & 0.114 & 0.041 & 78.0 & 25.9 & 18.1 & 4.2 \\
\hline Min. & 0.094 & 0.059 & 0.024 & 38.8 & 13.2 & 6.2 & 2.1 \\
\hline $2 \sigma / \bar{X}, \%$ & 15.3 & 23.4 & 23.8 & 28.3 & 29.1 & 38.1 & 28.7 \\
\hline \multicolumn{8}{|c|}{ Content in single grains } \\
\hline \multicolumn{8}{|c|}{$\mu g$} \\
\hline Av. & 19.3 & 13.3 & 5.20 & 0.90 & 0.30 & 0.18 & 0.05 \\
\hline Max. & 24.8 & 19.3 & 7.11 & 1.23 & 0.51 & 0.28 & 0.07 \\
\hline Min. & 14.3 & 9.4 & 3.48 & 0.69 & . 0.19 & 0.11 & 0.04 \\
\hline $2 \sigma / \bar{X}, \%$ & 19.7 & 26.2 & 30.0 & 24.9 & 33.2 & 30.6 & 32.7 \\
\hline
\end{tabular}

${ }^{\dagger}$ Wet digestion with $\mathrm{HNO}_{3}-\mathrm{H}_{2} \mathrm{O}_{2}$. Dry weight of single grains: Av. 17.4mg, Max. 21.1mg, Min. 13.8mg, 2б/X $18.9 \%$

ては適さないが，上記の他の元素の定量には適用可能で あり, 分解が速やかに終了するほか, 硝酸-過酸化水素 分解のように過酸化水素を少量ずつ滴下する手間もな く，簡便な方法であった。

NIES No.10 “玄米粉末” 標準試料は均一性を保証す るため, 1 点の分析に $400 \mathrm{mg}$ 以上を用いて分析するよ う指示している. その $1 / 20$ 量を用いて行った結果, 含 有量の多い主要な無機元素の分析では試料量 $20 \mathrm{mg}$ で も十分な精度を持つ測定が可能であった.

以上の結果から，ホウケイ酸ガラス製ねじ付き試験管 を用いた湿式分解を多数の少量試料の前処理として行う 場合, 硝酸-過塩素酸を用いた分解法では, $\mathrm{P}, \mathrm{K}, \mathrm{Mg}$,
$\mathrm{Ca}, \mathrm{Zn}, \mathrm{Fe}$ 及び $\mathrm{Cu}$ に適用可能であると判断した. 硝 酸-過酸化水素を用いる方法はこれらの元素に加えて Mn にも適用可能である.これらの方法は，コメだけで はなく，ほかの少量試料の分解にも用いることができる と考えられる。

\section{$3 \cdot 3$ コメ 1 粒の主要無機元素の測定}

$3 ・ 1$ 及び $3 ・ 2$ で検討したホウケイ酸ガラス製ねじ付 き武験管を用いる湿式分解法のうち, 硝酸-過酸化水素 を用いた方法で実際の玄米 1 粒を溶液化して無機元素 を測定した. 同一産地内の 1 粒の無機元素含有量の変 異を明らかにするため, 農業研究センタ一産 “日本晴” 
の玄米・精白米各 100 粒ずつを用い, $\mathrm{P}, \mathrm{K}, \mathrm{Mg}, \mathrm{Ca}$, $\mathrm{Zn}, \mathrm{Mn}, \mathrm{Fe}, \mathrm{Cu}$ を測定した， $\mathrm{P}$ を例にして, 乾重量 当たりの濃度の分布を Fig. 1 に示す. 又, これらの元 素について, Table 3 に玄米の結果を, Table 4 に精白 米の結果を示す. 1 粒のまま分解を行ったので, 反復測 定がない 1 粒につき 1 点の分析結果であり, 各元素の 測定において Table 2 のようなばらつきを持つことに は留意しなくてはならないが, 乾重量当たりの濃度, 1 粒中含有量とも $2 \sigma$ で平均值に対し，玄米では $\mathrm{P}, \mathrm{K}$, $\mathrm{Mg}$ で 15\% 前後, $\mathrm{Ca}, \mathrm{Zn}, \mathrm{Mn}, \mathrm{Fe}, \mathrm{Cu}$ で 20 40\% の変動があった，精白米の場合には，Fe が玄米でも含 有量が少量であるのに加え, 搗精による減少率の大きな 元素15)16)であることから, 測定值に対してから試験値 が高くなり, 定量が難しかった. 玄米に比較すると $\mathrm{K}$, $\mathrm{Mg}$ の変動がそれぞれ 23.4\%，23.8\% と大きくなった が, P, Ca， Zn, Mn, Cu は玄米とほぼ同様であった。 $\mathrm{K}, \mathrm{Mg}$ は特にコメ表面に多く分布していて搗精による 減少率が大きい元素であり, 削れ方の微妙な差違で精白 米中の含有量が左右されるために, 精白米の変動が大き くなったと考えられる.

これら玄米, 精白米の結果から, 無機元素含有量にお いても，コメには粒による個体差が存在し，こうした成 分の変異がコメ数粒もしくは1粒による機器での物性 測定におけるばらつきの原因の一つになっていると考え られる.

本研究において試料を提供していただいた農林水産省農 業研究センター稲育種研究室に感謝いたします.

$\left(\begin{array}{l}1996 \text { 年 } 3 \text { 月, 第 } 43 \text { 回日本食 } \\ \text { 品科学工学会にて一部発表 }\end{array}\right)$

\section{文献}

1) 杉山純一, 黒河内邦夫, 堀内久弥: 日本食品科学 工学会誌, 37, 61 (1990).

2) 乙部和紀: ジャパンフードサイエンス, 33 (8), 41 (1994).

3）稲津 脩: 北海道立農業試験場報告, 66,10 (1988).

4) 岡留博司, 豊島英親, 大坪研一: 日本食品科学工 学会誌, 43, 1004(1996).

5）稲津 脩: 北海道立農業試験場報告, 66, 34 (1988)

6) 石間紀男, 平 宏和, 平 春枝, 御子柴穆, 吉川 誠次: 食品総合研究所報告, 29, 9(1979).

7）堀野俊郎, 岡本正弘: 中国農業試験場報告, 10 , 1 (1992).

8) 井ノ内直良, 池内南美, 高美 正, 朝岡正子, 不 破英次：応用糖質科学, 43, 1 (1996).

9）鈴木保宏, 石川哲也, 池上 勝, 建部雅子, 小前 幸三: 育種学雑誌，44(別 2)，251 (1994).

10）河野澄夫, 倉内美奈, 草間豊子, 阿部英幸: 日本 食品科学工学会第 44 回大会講演集, p.51 (1997).

11) 寺本 薰: 育種学雑誌, $4 \mathbf{5}$ (別 2), 232 (1995).

12) M. L. Tracy, G. Möller: J. Assoc. Off. Anal. Chem., 73, 404 (1990).

13）堤 忠一: “食品分析法”, 第 2 版, 日本食品工 業学会食品分析法編集委員会編, p.32(1984), (光 琳).

14）安井明美, 鈴木忠直, 進藤久美子: 食品総合研究 所報告, 58, 37 (1994).

15）堤 忠一, 大家千恵子: 食品総合研究所報告, 33, 12 (1978).

16）進藤久美子, 安井明美: 食品総合研究所報告, 60, 17(1996).

\section{要旨}

コメ 1 粒のような少量試料中の無機元素測定法を検討した. コメ多数点をより迅速に処理するため, 分解容器にホウケイ酸ガラス製ねじ付き試験管を用い，これを多数装てんできる乾式ブロック浴で加熱 する湿式分解とし，硝酸に過酸化水素あるいは過塩素酸を組み合わせて分解を行った．硝酸一過酸化水 素分解では $150^{\circ} \mathrm{C}$ で分解操作を行い, 硝酸一過塩素酸分解では過塩素酸を蒸発させるため, 最終段階で $250^{\circ} \mathrm{C}$ に温度を上げた. ビちらの方法でも約 2 時間で 32 本の分解を行うことができた. 試験管内の分 解物は, $1 \%$ 塩酸を加えて溶解させた後, 誘導結合プラズマ発光分析装置で多元素同時定量し, 無機元 素含有量を求めた. コメ 1 粒分に相当する玄米標準試料の粉末約 $20 \mathrm{mg}$ を分解に用いて検討した結果, 硝酸-過酸化水素による分解がコメ 1 粒のような少量な試料における， P, K, Mg, $\mathrm{Ca}, \mathrm{Zn}, \mathrm{Mn}$, $\mathrm{Fe}, \mathrm{Cu}$ の測定の前処理法として適用可能であった. 含有量が低いため, Fe, $\mathrm{Cu}$ では相対標準偏差が 少し高かった．硝酸-過塩素酸では Mn の值が低くなったが，過塩素酸を蒸発させるために高温にした ことが原因と考えられた，硝酸一過酸化水素分解で実際の玄米，あるいは精白米の 100 粒を用いて，1 粒中の無機元素濃度を測定し，含有量の変異を調べたところ，同一産地内の “日本晴”ではこれら元素 の含有量は $2 \sigma$ で平均に対し，玄米で $\mathrm{P}, \mathrm{K}, \mathrm{Mg}$ に $15 \%$ 前後, $\mathrm{Ca}, \mathrm{Zn}, \mathrm{Mn}, \mathrm{Fe}, \mathrm{Cu}$ に $20 \sim 40 \%$ の変動が見られた。 